\title{
PERAN WORD OF MOUTH MEMEDIASI KUALITAS PRODUK TERHADAP KEPUTUSAN PEMBELIAN KONSUMEN
}

\author{
Ni Putu Dinda Prameswari Putri Astaki ${ }^{1}$ \\ Ni Made Purnami \\ ${ }^{1,2}$ Fakultas Ekonomi dan Bisnis Universitas Udayana (Unud), Bali, Indonesia \\ email: dindastaki@gmail.com
}

\begin{abstract}
ABSTRAK
Penelitian ini bertujuan untuk mengetahui pengaruh kualitas produk terhadap word of mouth dan keputusan pembelian, pengaruh word of mouth terhadap keputusan pembelian serta peran word of mouth memediasi pengaruh kualitas produk terhadap keputusan pembelian produk online shop Georgioswomen di Kota Denpasar. Penelitian dilakukan pada 100 responden berjenis kelamin perempuan di Kota Denpasar yang sudah pernah melakukan pembelian terhadap produk Georgioswomen. Jumlah responden ditentukan menggunakan metode purposive sampling, yaitu teknik penentuan sampel dengan pertimbangan tertentu. Data diperoleh dengan menyebarkan kuesioner yang dianalisis menggunakan teknik analisis jalur (path analysis) dan uji Sobel. Hasil pengujian menyatakan bahwa variabel kualitas produk berpengaruh positif dan signifikan terhadap word of mouth, variabel kualitas produk berpengaruh positif dan signifikan terhadap keputusan pembelian, variabel word of mouth berpengaruh positif dan signifikan terhadap keputusan pembelian, serta variabel word of mouth secara signifikan memediasi pengaruh kualitas produk terhadap keputusan pembelian.
\end{abstract}

Kata kunci: kualitas produk, word of mouth, keputusan pembelian, online shop

\begin{abstract}
This study aims to determine the effect of product quality on word of mouth and buying decisions, the effect of word of mouth on buying decisions and the role of word of mouth mediating the effect of product quality on Georgioswomen's product buying decisions in Denpasar. The study was conducted on 100 female in Denpasar who had made purchases on Georgioswomen. The number of respondents was determined using a purposive sampling method, namely the technique of determining samples with certain considerations. Data obtained by distributing questionnaires were analyzed using path analysis techniques (path analysis) and Sobel test. The test results state that product quality variables have a positive and significant effect on word of mouth, product quality variables have a positive and significant effect on buying decisions, word of mouth variables have a positive and significant effect on buying decisions, and word of mouth variables significantly mediate the effect of product quality against buying decisions.

Keywords: product quality, word of mouth, buying decisions, online shop
\end{abstract}




\section{PENDAHULUAN}

Seiring dengan kemajuan jaman dan teknologi, dunia bisnis banyak mengalami perubahan yang begitu cepat dan pesat, tidak sedikit pemasar konvensional beralih menjadi pemasar online. Konsumen memperoleh banyak manfaat dengan berbelanja secara online, yaitu lebih nyaman, produk lebih beragam, transaksi lebih cepat dan tanpa antrian, rahasia konsumen terlindungi, dan dapat menghemat waktu, tenaga, dan biaya (Tjahjono et al., 2013). Perkembangan dan persaingan bisnis dari tahun ke tahun mengalami banyak perubahan dan membuat pemasar harus berani memutar otak untuk dapat memenuhi kebutuhan konsumen agar mampu bersaing di dalam memasarkan produknya di pasaran. Pemasaran online (online shopping) merupakan upaya perusahaan untuk memasarkan produk dan jasa dan membangun hubungan dengan pelanggan melalui media internet (Kotler \& Armstrong, 2013:223). Namun, metode pemasaran tradisional yaitu promosi melalui word of mouth masih merupakan jenis aktivitas pemasaran yang paling efektif (Vibiznews-Sales \& Marketing, 2007). Pengeluaran operasi yang lebih rendah, dan keberhasilan bisnis yang tinggi menjadi titik fokus bagi bisnis (Ratanavilaikul, 2018).

Perusahaan harus bekerja keras dalam mempertahankan produknya untuk bisa bersaing dengan produk-produk yang lain (Sääksjärvi \& Samiee, 2011). Masalah yang ada saat ini adalah mengenai bagaimana pemasar menghasilkan produk yang memenuhi kebutuhan konsumen, bukan hanya bagaimana membuat konsumen puas dan loyal, namun perusahan juga dituntut mahir dalam melakukan promosi. Promosi ditujukan untuk mendapatkan pelanggan baru dan mempertahankan pelanggan yang ada (Wibowo \& Karimah, 2012). Seorang pemasar dituntut serta diharuskan untuk mampu membuat strategi pemasaran yang tepat supaya dapat memenangkan persaingan pasar, iklan atau promosi melalui berbagai media seperti radio, televisi, koran, atau media sosial menjadi cara yang tepat dan banyak dipilih oleh pemasar untuk dapat mempromosikan produk pemasar supaya lebih dikenal secara luas. Berbagai upaya dilakukan oleh perusahaan untuk meningkatkan penjualan perusahaan dan memuaskan kebutuhan pelanggannya. Disamping itu, iklan atau promosi yang menarik dapat membuat masyarakat merasa penasaran dan tertarik untuk mencoba membeli produk tersebut. Iklan atau promosi dapat menjadi pertimbangan dalam mengambil keputusan pembelian. Iklan dan promosi memberikan pengaruh yang sangat besar terhadap minat dan keputusan pembelian konsumen. Peran iklan dan promosi pada volume penjualan sangat penting (Tangkuman \& Saerang, 2016).

Proses pengambilan keputusan merupakan proses psikologis dasar yang memainkan peranan penting dalam memahami bagaimana konsumen secara aktual mengambil keputusan pembelian. Keputusan pembelian merupakan semua aspek dari afeksi dan kognisi yang terlibat dalam pembuatan keputusan konsumen, termasuk pengetahuan, makna, dan kepercayaan yang digerakkan dari memori dan atensi serta proses komperehensif yang terlibat di dalam interpretasi informasi baru di lingkungan (Supranto \& Limakrisna, 2011). Proses keputusan pembelian adalah proses yang dilalui pelanggan saat membeli suatu produk (Maria et al., 2016). 
Keputusan pembelian konsumen adalah serangkaian pilihan yang dibuat oleh konsumen sebelum melakukan pembelian (Oladepo \& Odunlami, 2015). Menurut Widiarsa \& Sulistyawati (2018), keputusan pembelian dapat didefinisikan sebagai proses yang berkeseinambungan, yang mengacu pada konsistensi tindakan yang bijaksana dan dilakukan untuk membawa kepuasan dalam kebutuhan. Ketika orang membeli sesuatu, mereka melalui beberapa tahap menimbang pilihan dan mencari alternatif sebelum mereka mengambil keputusan untuk melakukan pembelian

Para pemasar harus mendalami berbagai pengaruh terhadap pembeli dan mengembangkan pemahaman mengenai bagaimana sebenarnya para konsumen membuat keputusan pembelian mereka (Abdullah \& Tantri, 2012:123). Proses pengambilan keputusan pembelian diawali dengan adanya kebutuhan yang berusaha untuk dipenuhi. Pemenuhan kebutuhan ini terkait dengan beberapa alternatif sehingga perlu dilakukan evaluasi yang bertujuan untuk memperoleh alternatif terbaik dari persepsi konsumen (Kotler \& Keller, 2012).

Konsumen pemasaran melalui online shop di dalam melakukan keputusan pembelian biasanya didasari oleh kualitas dari produk yang bersangkutan. Kualitas dapat diartikan kemampuan dari produk untuk menjalankan fungsinya yang mencakup daya tahan, kehandalan atau kemajuan, kekuatan, kemudahan dalam pengemasan dan reparasi produk dan ciri-ciri lainnya (Luthfia, 2012). Produk didefinisikan sebagai persepsi konsumen yang dijabarkan oleh produsen melalui hasil produksinya. Mutu atau kualitas produk dipengaruhi oleh faktor yang akan menentukan bahwa mutu barang dapat memenuhi tujuannya, yaitu untuk meningkatkan volume penjualan (Iswayanti, 2010).

Kualitas produk adalah penggabungan karakteristik produk yang tercipta dari sistem pemasaran, proses produksi dan pemeliharaan yang membuat suatu produk menjadi unggul yang mampu memenuhi bahkan melebihi harapan konsumen (Wijaya, 2011:11). Banyak dari konsumen beranggapan bahwa mengetahui kualitas produk merupakan hal yang sangat penting sebelum mereka melakukan suatu keputusan pembelian. Setelah mereka mengetahui kualitas dari suatu produk, mereka akan mulai membicarakan dan tak jarang memberikan penilaian terhadap produk tersebut, kemudian terjadilah komunikasi dari mulut ke mulut atau yang biasa disebut dengan word of mouth. Keputusan pembelian seorang konsumen selain dipengaruhi oleh kualitas dari suatu produk, tidak jarang juga dipengaruhi oleh word of mouth.

Word of mouth merupakan komunikasi dari orang ke orang antara sumber pesan dan penerimanya mengenai suatu produk, brand, atau pelayanan (Alves et al., 2016). Word of mouth menjadi referensi yang membentuk harapan pelanggan akan suatu produk (Martín et al., 2015). Sumarwan (2015) mengartikan word of mouth sebagai pertukaran ide, pikiran, dan komentar antara dua atau lebih konsumen, dan tidak satupun dari mereka adalah pemasar. Word of mouth adalah bentuk komunikasi interpersonal diantara konsumen tentang pengalaman pribadi dengan produk atau perusahaan (Audrain-Pontevia et al., 2013). Word of mouth mempunyai pengaruh yang sangat besar kepada seseorang karena informasi yang didapat dianggap nyata dan jujur dan seseorang cenderung lebih mempercayai informasi produk yang mereka dengar dari teman, kerabat atau orang terdekat 
yang berpengalaman terhadap suatu produk tersebut dibandingkan dengan informasi dari iklan (Nugraha et al., 2015). Word of mouth mempengaruhi proses pengambilan keputusan konsumen ketika mereka berpikir akan membeli produk (Lerrthaitrakul \& Panjakajornsak, 2014). Word of mouth bertujuan untuk menyampaikan infromasi tentang atribut berbagai produk dan jasa, tentang penggunaan atau tentang produsen (Dzian et al., 2016). Word of mouth akan terjadi secara alami ketika orang menjadi pendukung suatu merek atau produk karena puas dengan produk yang dipakai atau dikonsumsinya dan memiliki hasrat atau keinginan yang muncul dari diri sendiri serta antusias untuk mengajak orang lain memilih merek atau produk yang telah dipakainya. Ismail \& Spinelli (2012) menyatakan bahwa terjadinya penyebaran WOM positif bersumber dari baiknya merek yang bersangkutan. Apabila konsumen cenderung merasa tidak puas dan mengalami penurunan akan minat pada suatu produk, word of mouth cenderung akan mengalami hal yang sama (Casaló et al., 2008). Komunikasi word of mouth yang efektif dapat mendukung konsumen dalam mengambil keputusan dalam memilih atau membeli produk dan jasa yang ditawarkan oleh berbagai perusahaan (Rukhiana, 2017).

Menurut penelitian Nugraha et al. (2015) variabel word of mouth memiliki pengaruh signifikan terhadap variabel keputusan pembelian, dan kemudian didukung juga oleh penelitian yang dilakukan Anwar (2015) yang menunjukkan bahwa kualitas produk berpengaruh secara positif dan signifikan terhadap keputusan pembelian konsumen. Semakin baik kualitas dari suatu produk, yang terjadi adalah word of mouth yang bersifat positif dan hal tersebut akan menyebabkan terjadinya keputusan pembelian yang dilakukan oleh konsumen dan begitupun sebaliknya.

Pentingnya memperhatikan kualitas suatu produk guna membuat konsumen tertarik untuk melakukan keputusan pembelian terhadap produknya menjadi perhatian salah satu pelaku pemasaran pakaian wanita Georgioswomen, yang merupakan salah satu pemasar online shop yang berdiri sejak tahun 2014 dan berlokasi di Denpasar, tepatnya di Jalan Tukad Badung no. 51. Georgioswomen merupakan pelaku online shop penjual pakaian wanita dengan segmen pasar wanita remaja dan dewasa. Georgioswomen memiliki desain pakaian wanita yang elegan dengan lebih banyak menggunakan pilihan warna monokrom (hitam dan putih), serta warna-warna pastel dan warna-warna lembut seperti krem, coklat muda dan abu-abu muda, dimana pada desain pakaian dari Georgioswomen terbilang eksklusif karena jarang ditemukan pada pemasar online shop sejenisnya, terbilang eksklusif juga karena pada setiap model pakaian disediakan tidak lebih dari 10 item per model pakaian demi menjaga agar produk tidak "pasaran", oleh karena kualitas produk yang dimiliki menyebabkan harga jual produk dari Georgioswomen memang terbilang sedikit lebih mahal dibanding pesaing dan online shop sejenisnya. Georgioswomen mengklaim produknya selalu menggunakan bahan dengan kualitas premium (dapat dilihat pada keterangan atau caption pada setiap foto katalog pakaian yang Georgioswomen unggah di akun instagramnya) oleh karena penggunaan bahan dengan kualitas premium itu Georgioswomen mematok harga sedikit lebih tinggi diatas pesaing sejenisnya mengingat kualitas bahan dan kualitas produknya yang terbilang baik karena 
konsumen selalu ingin mendapatkan produk yang berkualitas sesuai dengan harga yang dibayar, walaupun terdapat sebagian masyarakat yang berpendapat bahwa, produk yang mahal adalah produk yang berkualitas (Ong \& Sugiharto, 2013). Penetapan harga yang lebih tinggi mengingat kualitas yang ditawarkan seimbang dengan harga membuat Georgioswomen harus selalu menjaga kualitas bahan dari setiap produknya, oleh karena Georgioswomen merupakan online shop jadi membuat konsumen tidak mengetahui kualitas asli dari produk karena hanya melihat lewat media sosial saja, maka disinilah kekuatan word of mouth terjadi, calon konsumen akan bertanya atau mencari informasi dari orang lain atau kerabat yang sudah pernah melakukan pembelian sebelumnya kepada produk Georgioswomen, jika informasi yang didapat adalah kualitas produk yang bersangkutan dikatakan baik, hal tersebut akan membuat konsumen Georgioswomen menceritakan hal-hal positif tentang produk kepada orang lain, sehingga yang terjadi adalah word of mouth positif dimana hal ini dapat membuat konsumen melakukan suatu keputusan pembelian terhadap produk yang bersangkutan atau bahkan bisa terjadi pembelian ulang karena konsumen merasa bahwa harga yang sedikit mahal sesuai dengan kualitas yang ditawarkan, dan sebaliknya apabila Georgioswomen mematok harga yang lebih mahal dengan kualitas yang buruk, konsumen akan menceritakan kekurangan produk sehingga dapat menyebabkan konsumen berpikir dua kali atau bahkan tidak melakukan keputusan pembelian sama sekali. Word of mouth tentu saja secara tidak langsung menimbulkan niat konsumen untuk melakukan keputusan pembelian atau tidak terhadap suatu produk, word of mouth memang mempunyai pengaruh yang sangat besar kepada seseorang karena informasi yang didapat dianggap nyata dan jujur (Nugraha et al., 2015). Secara teori, jika konsumen merasa puas akan suatu produk, layanan, atau merek, mereka akan lebih cenderung untuk terus membeli dan memberitahu orang-orang tentang pengalaman yang menguntungkan mereka dengan produk yang bersangkutan (Olson \& Paul, 2014).

Hasil penelitian (Irwanto et al., 2013) menyatakan bahwa kualitas produk berpengaruh positif dan signifikan terhadap word of mouth positif, dan hasil penelitian Rusadi \& Sujito (2012) yang menyatakan bahwa kualitas produk berpengaruh positif terhadap word of mouth positif. Jika suatu produk memiliki kualitas dan mutu yang baik maka konumen akan merasa senang menggunakan produk yang bersangkutan dan pada akhirnya akan timbul perilaku positif dan memberikan tanggapan postif dan rekomendasi positif kepada orang lain, pelanggan yang merasa puas terhadap kualitas produk yang diberikan oleh perusahaan juga cenderung akan melakukan rekomendasi dari mulut ke mulut (word of mouth) positif kepada orang lain (Puspasari, 2014). Produk yang memiliki kualitas dan mutu yang rendah maka konsumen akan memberikan tanggapan negatif dan rekomendasi yang negatif. Berdasarkan dari hasil penelitian sebelumnya, maka pada penelitian ini dapat ditarik hipotesis sebagai berikut:

$\mathrm{H}_{1}$ : Kualitas produk berpengaruh positif dan signifikan terhadap word of mouth.

Adanya pengaruh word of mouth dalam suatu pemasaran akan membawa dampak yang amat besar terhadap suatu produk itu sendiri, apabila word of mouth 
bersifat positif, maka hal tersebut akan membuat konsumen untuk melakukan keputusan pembelian terhadap produk yang bersangkutan. Menurut penelitian yang dilakukan oleh Nugraha et al. (2015) variabel word of mouth memiliki pengaruh signifikan terhadap variabel keputusan pembelian,informasi positif yang didapat oleh calon konsumen mengenai suatu produk mendorong konsumen untuk melakukan keputusan pembelian pada. Hasil penelitian ini didukung oleh teori yang dikemukakan oleh Molinari et al. (2008) yaitu pembelian dan positif word of mouth saling berhubungan. Konsumen akan melakukan kegiatan word of mouth dan menceritakan pengalaman mereka setelah mengkonsumsi produk kepada orang lain seperti sahabat, kerabat, dan teman. Apabila pengalaman yang diperoleh positif maka word of mouth yang dilakukan juga positif dan begitu pula sebaliknya. Berdasarkan dari hasil penelitian sebelumnya, maka pada penelitian ini dapat ditarik hipotesis sebagai berikut:

$\mathrm{H}_{2}$ : Word of mouth berpengaruh positif dan signifikan terhadap keputusan pembelian konsumen

Konsumen dapat mengambil keputusan untuk membeli sebuah barang atau jasa ketika konsumen tersebut menganggap produk itu dibutuhkan. Kualitas produk yang diberikan perusahaan adalah strategi yang tepat untuk menarik perhatian konsumen. Hal ini di dukung oleh penelitian yang dilakukan oleh Anwar (2015) yang menunjukkan bahwa kualitas produk berpengaruh terhadap keputusan pembelian. Pendapat tersebut juga didukung oleh penelitian yang dilakukan oleh Anis et al. (2015) yang mengungkapkan bahwa kualitas produk yang dianggap baik oleh konsumen akan menciptakan keputusan pembelian. Keputusan pembelian akan dilakukan ketika konsumen sudah memilih. Kemudian didukung juga oleh pendapat (Ries \& Trout, 2002:51) yang mengatakan bahwa kualitas produk akan menjadi pertimbangan penting bagi pembelian. Lebih lanjut menurut Rijswijk \& Frewer (2008) menyatakan bahwa persepsi konsumen yang positif terhadap suatu kualitas produk akan berdampak pada pilihan konsumen dalam memutuskan membeli. Berdasarkan dari hasil penelitian sebelumnya, maka pada penelitian ini dapat ditarik hipotesis sebagai berikut:

$\mathrm{H}_{3}$ : Kualitas produk berpengaruh positif dan signifikan terhadap keputusan pembelian konsumen

Menurut penelitian yang dilakukan terdahulu oleh (Nugraha et al., 2015) variabel word of mouth memiliki pengaruh signifikan terhadap variabel keputusan pembelian, dan juga didukung penelitian dari Anwar (2015) yang menunjukkan bahwa kualitas produk berpengaruh terhadap keputusan pembelian. Artinya semakin baik kualitas dari suatu produk, hal tersebut akan menyebabkan terjadinya word of mouth yang bersifat positif, apabila yang terjadi adalah word of mouth positif, maka cenderung akan terjadi keputusan pembelian oleh konsumen terhadap produk yang bersangkutan. Sebaliknya, apabila produk yang bersangkutan memiliki kualitas yang buruk, yang terjadi adalah word of mouth negatif dan hal tersebut kemungkinan menyebabkan tidak akan ada keputusan 
pembelian yang dilakukan oleh konsumen. Word of mouth secara signifikan memediasi kualitas produk terhadap keputusan pembelian konsumen.

$\mathrm{H}_{4}$ : Word of mouth secara positif dan signifikan memediasi pengaruh kualitas produk terhadap keputusan pembelian konsumen.

\section{METODE PENELITIAN}

Kota Denpasar dipilih sebagai lokasi untuk dilakukannya penelitian ini dengan pertimbangan lokasi online shop Georgioswomen berada di Kota Denpasar dan sebagian besar konsumen Georgioswomen berada di Kota Denpasar. Variabel eksogen dalam penelitian ini adalah kualitas produk (X). Variabel endogen dalam penelitian ini adalah keputusan pembelian $\left(\mathrm{Y}_{2}\right)$. Variabel mediasi dalam penelitian ini adalah word of mouth $\left(\mathrm{Y}_{1}\right)$. Indicator variabel penelitian dapat dijelaskan dalam Tabel 1 di bawah ini:

Tabel 1.

Indikator Variabel Penelitian

\begin{tabular}{|c|c|c|c|}
\hline No & Variabel & Indikator & Sumber \\
\hline 1 & $\begin{array}{l}\text { Kualitas produk } \\
\text { (X) }\end{array}$ & $\begin{array}{l}\text { 1). Kenyamanan produk (X1) } \\
\text { 2). Daya tahan produk (X2) } \\
\text { 3). Keindahan desain (X3) } \\
\text { 4). Keragaman produk (X4) }\end{array}$ & $\begin{array}{ll}\text { Fandy } & \text { Tjiptono } \\
(2008) & \end{array}$ \\
\hline 2 & $\begin{array}{l}\text { Word of mouth } \\
\left(\mathrm{Y}_{1}\right)\end{array}$ & $\begin{array}{l}\text { 1). Mengetahui produk dari orang lain } \\
\left(\mathrm{Y}_{1} 1\right) \\
\text { 2). Percaya dengan informasi yang } \\
\text { diberikan }\left(\mathrm{Y}_{1} 2\right) \\
\text { 3). Mengajak konsumen lain }\left(\mathrm{Y}_{1} 3\right)\end{array}$ & $\begin{array}{l}\text { Yuly Rahmi } \\
\text { Pratiwi (2017) }\end{array}$ \\
\hline 3 & $\begin{array}{l}\text { Keputusan } \\
\text { pembelian }\left(\mathrm{Y}_{2}\right)\end{array}$ & $\begin{array}{l}\text { 1). Adanya kebutuhan atau keinginan } \\
\text { yang mendasari keputusan } \\
\text { pembelian (Y1) } \\
\text { 2). Keputusan pembelian atas dasar } \\
\text { informasi yang diberikan (Y2) } \\
\text { 3). Seleksi terhadap beberapa alternatif } \\
\text { (Y3) } \\
\text { 4). Kemantapan produk (Y4) } \\
\text { 5). Melakukan pembelian ulang (Y5) }\end{array}$ & $\begin{array}{l}\text { Martoatmodjo } \\
(2012)\end{array}$ \\
\hline
\end{tabular}

Sumber: Data diolah, 2018

Responden dalam penelitian ini adalah 147 orang konsumen Georgioswomen di Denpasar yang berjenis kelamin perempuan yang telah mengisi kuisioner online yang telah disebarkan oleh peneliti. Penelitian ini menggunakan 13 indikator dengan menggunakan jumlah responden sebanyak 100 orang karena sebanyak 47 orang yang telah mengisi kuisioner online tidak memenuhi syarat dan kriteria untuk digunakan sebagai sampel didalam penelitian ini. 
Metode penentuan sampel yang digunakan pada penelitian ini adalah metode non probability sampling dengan teknik pengambilan sampel yang digunakan dalam penelitian ini adalah purposive sampling, yaitu sampel ditentukan dengan pertimbangan tertentu.

Data dalam penelitian ini dikumpulkan melalui kuesioner. Metode pengumpulan data berupa penyebaran kuesioner yang secara langsung disebarkan oleh peneliti. Kuesioner terdiri dari pertanyaan terbuka yaitu identitas diri responden dan pertanyaan tertutup yaitu pernyataan - pernyataan yang telah disediakan dan jawaban yang diberikan dibatasi.

Teknik analisis statistik dalam penelitian ini adalah teknik analisis jalur (Path Analysis). Analisis jalur digunakan untuk menentukan pola hubungan antara tiga atau lebih dan tidak dapat digunakan untuk mengkonfirmasi atau menolak hipotesis. Pengujian hipotesis mediasi dapat dilakukan dengan prosedur yang dikembangkan oleh Sobel (1982) dan dikenal dengan Uji Sobel (Sobel Test). Uji Sobel digunakan dengan menguji kekuatan pengaruh tidak langsung variabel kualitas produk $(\mathrm{X})$ terhadap variabel keputusan pembelian $\left(\mathrm{Y}_{2}\right)$ melalui variabel word of mouth $\left(\mathrm{Y}_{1}\right)$.

\section{HASIL DAN PEMBAHASAN}

Responden pada penelitian ini berjumlah 100 orang sesuai dengan ukuran sampel yang digunakan. Responden penelitian akan digambarkan dengan menyajikan karakteristik responden yang terdiri dari umur, pekerjaan beserta pendidikan terakhir yang disajikan pada Tabel 2 .

Tabel 2.

Karakteristik Responden

\begin{tabular}{|c|c|c|c|c|}
\hline No & Kriteria & Klasifikasi & Jumlah (Orang) & Persentase \\
\hline \multirow[t]{5}{*}{1} & Usia & $17-20$ & 31 & 31 \\
\hline & & $21-25$ & 60 & 60 \\
\hline & & $25-35$ & 5 & 5 \\
\hline & & $>35$ & 4 & 4 \\
\hline & Jumlah & & 100 & 100 \\
\hline \multirow[t]{5}{*}{2} & Pendidikan & SMA/SMK & 70 & 70 \\
\hline & & Diploma & 7 & 7 \\
\hline & & S1 & 21 & 21 \\
\hline & & Pasca Sarjana & 2 & 2 \\
\hline & Jumlah & & 100 & 100 \\
\hline \multirow[t]{5}{*}{3} & Pekerjaan & Mahasiswa & 68 & 68 \\
\hline & & PNS & 1 & 1 \\
\hline & & Swasta & 18 & 18 \\
\hline & & Lain-lain & 13 & 13 \\
\hline & Jumlah & & 100 & 100 \\
\hline
\end{tabular}

Sumber: Data Primer diolah. 
Kondisi ini menunjukkan bahwa secara umum responden pada penelitian ini didominasi oleh responden yang berusia antara 21 hingga 25 tahun dengan presentase sebanyak 60 persen dan responden dengan usia lebih dari 35 tahun mendapatkan presentase terrendah sebanyak 4 persen. Kemudian diikuti oleh pendidikan terakhir yang didominasi pendidikan terakhir SMA/SMK dengan presentase sebanyak 70 persen dan paling kecil pasca sarjana sebanyak 2 persen. Pekerjaan didominasi oleh mahasiswa sebanyak 68 persen dan paling kecil oleh PNS dengan presentase hanya 1 persen.

Instrumen pertanyaan dalam kuesioner dikatakan valid apabila koefisien korelasi $\geq 0,30$ (Sugiyono, 2017). Uji validitas bertujuan untuk memeriksa apakah kuesioner sebagai instrumen penelitian sudah tepat untuk mengukur indikator dalam penelitian.

Tabel 3.

Hasil Uji Validitas Instrumen

\begin{tabular}{|c|c|c|c|c|}
\hline No & Variabel & Item Pernyataan & $\begin{array}{c}\text { Korelasi Item } \\
\text { Total } \\
\end{array}$ & Keterangan \\
\hline \multirow[t]{5}{*}{1} & \multirow{5}{*}{ Kualitas Produk (X) } & $\mathrm{X}_{1.1}$ & 0,886 & Valid \\
\hline & & $\mathrm{X}_{1.2}$ & 0,866 & Valid \\
\hline & & $\mathrm{X}_{1.3}$ & 0,884 & Valid \\
\hline & & $\mathrm{X}_{1.4}$ & 0,838 & Valid \\
\hline & & $\mathrm{X}_{1.5}$ & 0,706 & Valid \\
\hline \multirow[t]{4}{*}{2} & \multirow{4}{*}{ Word of Mouth (Y1) } & $\mathrm{Y}_{1.1}$ & 0,902 & Valid \\
\hline & & $\mathrm{Y}_{1.2}$ & 0,851 & Valid \\
\hline & & $\mathrm{Y}_{1.3}$ & 0,886 & Valid \\
\hline & & $\mathrm{Y}_{1.4}$ & 0,914 & Valid \\
\hline \multirow[t]{4}{*}{3} & \multirow{4}{*}{$\begin{array}{l}\text { Keputusan Pembelian } \\
\text { (Y2) }\end{array}$} & $\mathrm{Y}_{2.1}$ & 0,827 & Valid \\
\hline & & $\mathrm{Y}_{2.2}$ & 0,829 & Valid \\
\hline & & $\mathrm{Y}_{2.3}$ & 0,909 & Valid \\
\hline & & $\mathrm{Y}_{2.4}$ & 0,941 & Valid \\
\hline
\end{tabular}

Sumber: Data Primer diolah 2018.

Hasil uji validitas instrumen penelitian disajikan dalam tabel 3 yang menunjukkan bahwa seluruh indikator pernyataan dalam variabel kualitas produk, word of mouth dan keputusan pembelian produk pakaian wanita Georgioswomen di Kota Denpasar memiliki korelasi item total lebih besar atau sama dengan dari 0,30 sehingga seluruh indikator tersebut telah memenuhi syarat validitas data.

Hasil uji reliabilitas instrumen penelitian untuk menetapkan apakah instrumen kuesioner dapat digunakan lebih dari satu kali, dengan responden yang sama disajikan Tabel 4 yang menunjukkan bahwa ketiga instrument penelitian yaitu variabel kualitas produk, word of mouth dan keputusan pembelian produk pakaian wanita Georgioswomen di Kota Denpasar memiliki koefisien cronbach's alpha $>0,60$ sehingga pernyataan pada kuesioner tersebut reliabel.

Uji Normalitas bertujuan untuk mengetahui apakah residual dari model regresi yang dibuat berdistribusi normal atau tidak. Untuk menguji apakah data yang digunakan normal atau tidak dapat dilakukan dengan menggunakan uji 
Kolmogorov Smirnov Apabila koefisien Asymp. Sig. (2-tailed) lebih besar dari 0,05 maka data tersebut dikatakan berdistribusi normal.

Tabel 4.

Hasil Uji Reliabilitas Instrumen

\begin{tabular}{cccc}
\hline No & Variabel & Cronbach's Alpha & Keterangan \\
\hline 1 & Kualitas Produk $(\mathrm{X})$ & 0.892 & Reliabel \\
2 & Word of Mouth $(\mathrm{Y} 1)$ & 0.911 & Reliabel \\
3 & Keputusan Pembelian $(\mathrm{Y} 2)$ & 0.900 & Reliabel \\
\hline
\end{tabular}

Sumber: Data Primer diolah, 2018

Tabel 5.

Hasil Uji Normalitas Struktur 1

\begin{tabular}{lc}
\hline & Unstandardized Residual \\
\hline $\mathrm{N}$ & 100 \\
Kolmogorov-Smirnov $Z$ & 0,579 \\
Asymp.Sig.(2-tailed) & 0,891 \\
\hline Sumber Detal &
\end{tabular}

Sumber: Data diolah, 2018

Berdasarkan Tabel 5. dapat dilihat bahwa nilai Kolmogorov Smirnov (K-S) sebesar 0,579, sedangkan nilai Asymp. Sig. (2-tailed) sebesar 0,891. Hasil tersebut mengindikasikan bahwa model persamaan regresi tersebut berdistribusi normal karena nilai Asymp. Sig. (2-tailed) lebih besar dari nilai alpha 0,05.

Tabel 6.

Hasil Uji Normalitas Struktur 2

\begin{tabular}{lc}
\hline & Unstandardized Residual \\
\hline $\mathrm{N}$ & 100 \\
Kolmogorov-Smirnov Z & 0,890 \\
Asymp.Sig.(2-tailed) & 0,407 \\
\hline Sumber: Data diolah, 2018 &
\end{tabular}

Berdasarkan Tabel 6. dapat dilihat bahwa nilai Kolmogorov Smirnov (K-S) sebesar 0,890, sedangkan nilai Asymp. Sig. (2-tailed) sebesar 0,407. Hasil tersebut mengindikasikan bahwa model persamaan regresi tersebut berdistribusi normal karena nilai Asymp. Sig. (2-tailed) lebih besar dari nilai alpha 0,05.

Uji ini bertujuan untuk menguji apakah pada model regresi ditemukan adanya korelasi antar variabel bebas. Adanya multikolinearitas dapat dilihat dari nilai tolerance atau variance inflation factor (VIF). Jika nilai tolerance lebih dari $10 \%$ atau VIF Kurang dari 10, maka dikatakan tidak ada multikolinearitas.

Tabel 7.

Hasil Uji Multikolinearitas

\begin{tabular}{ccc}
\hline Variabel & Tolerance & VIF \\
\hline Kualitas Produk (X) & 0,508 & 1,970 \\
Word of Mouth (Y1) & 0,508 & 1,970 \\
\hline
\end{tabular}


Berdasarkan Tabel 7. dapat dilihat bahwa nilai tolerance dan VIF dari variabel kualitas produk dan word of mouth menunjukkan nilai tolerance untuk setiap variabel lebih besar dari 10\% dan nilai VIF lebih kecil dari 10 yang berarti model persamaan regresi bebas dari multikolinearitas.

Apabila asumsi heteroskedastisitas tidak terpenuhi, maka model regresi dinyatakan tidak valid sebagai alat peramalan dan pengujian ini dilakukan dengan Uji Glejser. Jika nilai signifikansinya di atas 0,05 maka tidak mengandung gejala heteroskedastisitas.

Tabel 8.

Hasil Uji Heteroskedastisitas Struktur 1

\begin{tabular}{|c|c|c|c|c|c|}
\hline \multirow[b]{2}{*}{ Model } & \multicolumn{2}{|c|}{ Unstandardized Coefficients } & \multirow{2}{*}{$\begin{array}{c}\text { Standardized } \\
\text { Coefficients } \\
\text { Beta }\end{array}$} & \multirow[b]{2}{*}{$\mathbf{T}$} & \multirow{3}{*}{$\frac{\text { Sig. }}{335}$} \\
\hline & B & Std. Error & & & \\
\hline $1 \quad$ (Constant) & .196 & .202 & & .970 & \\
\hline Kualitas Produk & .038 & .049 & .079 & .780 & .438 \\
\hline
\end{tabular}

Sumber: Data diolah, 2018

Pada Tabel 8. dapat dilihat bahwa nilai signifikansi dari variabel kualitas produk sebesar 0,438. Nilai tersebut lebih besar dari 0,05 yang berarti tidak terdapat pengaruh antara variabel bebas terhadap absolute residual. Sehingga model yang dibuat tidak mengandung gejala heteroskedastisitas.

Tabel 9.

Hasil Uji Heteroskedastisitas Struktur 2

\begin{tabular}{|c|c|c|c|c|c|c|}
\hline \multirow{2}{*}{\multicolumn{2}{|c|}{ Model }} & \multicolumn{2}{|c|}{$\begin{array}{l}\text { Unstandardized } \\
\text { Coefficients }\end{array}$} & \multirow{2}{*}{$\begin{array}{c}\text { Standardized } \\
\text { Coefficients } \\
\text { Beta } \\
\end{array}$} & \multirow[b]{2}{*}{$\mathbf{T}$} & \multirow[b]{2}{*}{ Sig. } \\
\hline & & B & Std. Error & & & \\
\hline \multirow[t]{3}{*}{2} & (Constant) & .471 & .187 & & 2.517 & .013 \\
\hline & Kualitas Produk & .060 & .062 & .136 & .974 & .333 \\
\hline & Word of Mouth & -.111 & .057 & -.274 & -1.965 & .052 \\
\hline
\end{tabular}

Sumber: Data diolah, 2018

Pada Tabel 9. dapat dilihat bahwa nilai signifikansi dari variabel kualitas produk sebesar 0,333, dan variabel word of mouth sebesar 0,052. Nilai tersebut lebih besar dari 0,05 yang berarti tidak terdapat pengaruh antara variabel bebas terhadap absolute residual. Sehingga model yang dibuat tidak mengandung gejala heteroskedastisitas.

Tabel 10.

Hasil Analisis Jalur Persamaan Regresi 1

\begin{tabular}{lcccc}
\hline \multicolumn{1}{c}{ Variabel } & Standardized Coefficients & Std. Error & t hitung & Sig. uji t \\
\hline (Constant) & & 0,327 & 1,992 & 0,049 \\
Kualitas Produk (X) & 0,702 & 0,079 & 9,749 & 0,000 \\
R Square & 0,492 & & & \\
F Statistik & 95,052 & & & \\
Signifikansi Uji F & 0,000 & &
\end{tabular}


Berdasarkan hasil analisis jalur substruktur 1 seperti yang disajikan pada Tabel 10 maka persamaan strukturalnya adalah sebagai berikut:

$$
\begin{aligned}
& M=\beta_{1} X+e_{1} \\
& M=0,702 X
\end{aligned}
$$

Berdasarkan hasil analisis pengaruh pengaruh kualitas produk terhadap word of mouth diperoleh nilai Sig $\mathrm{t}$ sebesar 0,000 dengan nilai koefisien beta sebesar 0,702 Nilai Sig. t 0,000 $\leq 0,05$ mengindikasikan bahwa $\mathrm{H}_{0}$ ditolak dan $\mathrm{H}_{1}$ diterima. Hasil ini mempunyai arti bahwa kualitas produk berpengaruh positif dan signifikan terhadap word of mouth.

Tabel 11.

Hasil Analisis Jalur Persamaan Regresi 2

\begin{tabular}{lcccc}
\hline \multicolumn{1}{c}{ Variabel } & Standardized Coefficients & Std. Error & t hitung & Sig. uji t \\
\hline (Constant) & & 0,292 & 1,348 & 0,181 \\
Kualitas Produk (X) & 0,519 & 0,097 & 5,905 & 0,000 \\
Word of Mouth (Y1) & 0,331 & 0,088 & 3,773 & 0,000 \\
R Square & 0,620 & & & \\
F Statistik & 79,160 & & & \\
Signifikansi Uji F & 0,000 & & & \\
\hline S & & &
\end{tabular}

Sumber: Data diolah, 2018

Berdasarkan hasil analisis jalur substruktural 2 seperti yang disajikan pada tabel 11, maka persamaan strukturalnya adalah sebagai berikut:

$$
\begin{aligned}
& Y=\beta_{2} X+\beta_{3} \mathrm{M}+\mathrm{e}_{1} \ldots \\
& \mathrm{Y}=0,519 \mathrm{X}+0,331 \mathrm{M}
\end{aligned}
$$

Berdasarkan hasil analisis pengaruh pengaruh kualitas produk terhadap keputusan pembelian diperoleh nilai Sig t sebesar 0,000 dengan nilai koefisien beta sebesar 0,519 Nilai Sig. t 0,000 $\leq 0,05$ mengindikasikan bahwa $\mathrm{H}_{0}$ ditolak dan $\mathrm{H}_{1}$ diterima. Hasil ini mempunyai arti bahwa kualitas produk berpengaruh positif dan signifikan terhadap keputusan pembelian.

Berdasarkan hasil analisis pengaruh pengaruh word of mouth terhadap keputusan pembelian diperoleh nilai Sig t sebesar 0,000 dengan nilai koefisien beta sebesar 0,331 Nilai Sig. t $0,000 \leq 0,05$ mengindikasikan bahwa $\mathrm{H}_{0}$ ditolak dan $\mathrm{H}_{1}$ diterima. Hasil ini mempunyai arti bahwa word of mouth berpengaruh positif dan signifikan terhadap keputusan pembelian.

Berdasarkan model substruktur 1 dan model substruktur 2, maka dapat disusun model diagram jalur akhir. Sebelum menyusun model diagram jalur akhir, terlebih dahulu dihitung nilai standar error sebagai berikut:

$$
\begin{aligned}
& \mathrm{e}=\sqrt{1-R^{2}} \ldots \ldots \ldots \ldots \ldots \ldots \ldots \ldots \ldots \\
& \mathrm{e}_{1}=\sqrt{1-R 1^{2}}=\sqrt{1-0,492}=0,712
\end{aligned}
$$


$\mathrm{e}_{2}=\sqrt{1-R 2^{2}}=\sqrt{1-0,620}=0,616$

Berdasarkan perhitungan pengaruh error (e), didapatkan hasil pengaruh error $\left(\mathrm{e}_{1}\right)$ sebesar 0,712 dan pengaruh error $\left(\mathrm{e}_{2}\right)$ sebesar 0,616 .

Hasil koefisien determinasi total adalah sebagai berikut:

$$
\begin{aligned}
\mathrm{R}^{2} \mathrm{~m} & =1-\left(\mathrm{Pe}_{1}\right)^{2}\left(\mathrm{Pe}_{2}\right)^{2} \ldots \ldots \\
& =1-(0,712)^{2}(0,616)^{2} \\
& =1-(0,506)(0,379) \\
& =1-0,192 \\
& =0,808
\end{aligned}
$$

Nilai determinasi total sebesar 0,808 mempunyai arti bahwa sebesar 80,8 persen variasi keputusan pembelian dipengaruhi oleh variasi kualitas produk dan variasi word of mouth, sementara sisanya sebesar 19,2 persen dijelaskan oleh

\begin{tabular}{|c|c|c|c|}
\hline $\begin{array}{c}\text { Pengaruh } \\
\text { Variabel }\end{array}$ & $\begin{array}{l}\text { Pengaruh } \\
\text { Langsung }\end{array}$ & $\begin{array}{c}\text { Pengaruh Tidak Langsung } \\
\text { Melalui Word of Mouth }(\mathrm{Y} 1)=\left(\beta_{1}\right. \\
\left.\text { x } \beta_{3}\right)\end{array}$ & Pengaruh Total \\
\hline $\mathrm{X} \rightarrow \mathrm{Y} 1$ & 0,702 & - & 0,702 \\
\hline $\mathrm{X} \longrightarrow \mathrm{Y} 2$ & 0,519 & 0,232 & 0,751 \\
\hline $\mathrm{Y} 1 \longrightarrow \mathrm{Y} 2$ & 0,331 & - & 0,331 \\
\hline
\end{tabular}
faktor lain yang tidak dimasukkan ke dalam model.

Tabel 12.

Pengaruh Langsung, Pengaruh Tidak Langsung serta Pengaruh Total Kualitas Produk (X), Word of Mouth (Y1), dan Keputusan Pembelian (Y2)

Sumber: Data diolah, 2018

$$
\begin{aligned}
\mathrm{VAF} & =\left(\beta_{1} \times \beta_{3}\right):\left(\beta_{1} \times \beta_{3}+\beta_{2}\right) \ldots \ldots \ldots \ldots \ldots \ldots \ldots \\
& =(0,702 \times 0,331):(0,702 \times 0,331+0,519) \\
& =(0,232):(0,751) \\
& =0,308=30,8 \% \text { (mediasi sebagian / parsial })
\end{aligned}
$$

Berpedoman pada kriteria jika nilai VAF diatas $80 \%$, maka menunjukkan peran pemediasi penuh (full mediation), jika VAF bernilai di antara 20\%-80\%, maka dapat dikategorikan sebagai pemediasi parsial, dan jika nilai VAF kurang dari $20 \%$, dapat disimpulkan bahwa hampir tidak ada efek mediasi. Dapat disimpulkan bahwa hasil uji VAF adalah sebesar 30,8\%, termasuk mediasi sebagian / mediasi parsial.

Uji Sobel digunakan dengan menguji kekuatan pengaruh tidak langsung variabel kualitas produk $(\mathrm{X})$ terhadap variabel keputusan pembelian (Y2) melalui variabel word of mouth (Y2). Uji sobel dirumuskan dengan persamaan berikut dan dapat dihitung dengan menggunakan aplikasi Microsoft Excel 2010. Bila nilai kalkulasi Z lebih besar dari 1,96 (dengan tingkat kepercayaan 95 persen), maka variabel mediator dinilai secara signifikan memediasi hubungan antara variabel endogen dan variabel eksogen. 
$\mathrm{Sa} 2 \mathrm{~b}=\sqrt{\mathrm{a}^{2} \mathrm{Sb}^{2}+\mathrm{b}^{2} \mathrm{Sa}^{2}+\mathrm{Sa}^{2} \mathrm{Sb}^{2}}$

Keterangan:

$$
\begin{aligned}
\mathrm{a} & =0,702 \quad \mathrm{~b}=0,331 \\
\mathrm{Sa} & =0,079 \quad \mathrm{Sb}=0,088 \\
\mathrm{Sa} 2 \mathrm{~b} & =\sqrt{0,702^{2} 0,088^{2}+0,331^{2} 0,079^{2}+0,079^{2} 0,088^{2}} \\
& =\sqrt{0,0038+0,0007+0,0000} \\
& =\sqrt{0,0045} \\
& =0,067442 \\
\mathrm{Z} & =\frac{a b}{S a 2 b} \ldots \ldots \ldots \ldots \ldots \ldots \ldots \ldots \ldots \ldots \ldots \ldots \ldots \ldots \ldots \\
& =\frac{0,2324}{0,067442} \\
& =3,4454
\end{aligned}
$$

Berdasarkan hasil Uji Sobel dalam penelitian ini menunjukkan bahwa hasil tabulasi $\mathrm{Z}=3,4454>1,96$ dengan tingkat signifikansi $0,000<0,05$ yang berarti variabel mediasi yakni word of mouth dinilai secara signifikansi mampu memediasi pengaruh kualitas produk terhadap keputusan pembelian produk pakaian wanita online shop Georgioswomen di Kota Denpasar.

Tujuan dilakukannya penelitian ini adalah untuk mengetahui pengaruh kualitas produk terhadap word of mouth konsumen. Berdasarkan hasil olah data diperoleh nilai koefisien beta positif sebesar 0,702 dengan tingkat signifikansi sebesar 0,000 (kurang dari 0,05) yang artinya $\mathrm{H}_{1}$ diterima. Hal ini mengindikasikan bahwa variabel kualitas produk secara positif dan signifikan berpengaruh terhadap variabel word of mouth. Hasil ini berarti bahwa semakin tinggi kualitas yang dimiliki oleh suatu produk maka akan semakin baik pula word of mouth yang terjadi pada produk tersebut.

Hasil penelitian ini sejalan dengan beberapa hasil penelitian - penelitian sebelumnya yang telah dilakukan oleh Irwanto et al. (2013), Rusadi \& Sujito (2012), dan Puspasari (2014), menunjukkan hasil yang positif dan signifikan antara pengaruh kualitas produk terhadap word of mouth konsumen.

Tujuan dilakukannya penelitian ini adalah untuk mengetahui pengaruh kualitas produk terhadap keputusan pembelian konsumen. Berdasarkan hasil olah data diperoleh nilai koefisien beta positif sebesar 0,519 dengan tingkat signifikansi sebesar 0,000 (kurang dari 0,05 ) yang artinya $\mathrm{H}_{1}$ diterima. Hasil ini berarti bahwa semakin tinggi kualitas produk yang dimiliki suatu produk maka akan semakin meningkat pula keputusan pembelian konsumen pada produk tersebut.

Hasil penelitian ini mendukung beberapa hasil penelitian sebelumnya yang telah dilakukan oleh Ries \& Trout (2002), Rijswijk \& Frewer (2008), Anwar 
(2015) serta penelitian yang dilakukan oleh Anis et al. (2015) menunjukkan hasil yang positif dan signifikan antara pengaruh kualitas produk terhadap keputusan pembelian konsumen.

Penelitian ini bertujuan untuk mengetahui pengaruh word of mouth terhadap keputusan pembelian konsumen. Berdasarkan hasil olah data diperoleh nilai koefisien beta positif sebesar 0,331 dengan tingkat signifikan sebesar 0,000 (kurang dari 0,05 ) yang artinya $\mathrm{H}_{1}$ diterima. Hasil ini berarti bahwa semakin positif word of mouth yang ditunjukkan oleh konsumen terhadap suatu produk maka akan semakin tinggi pula keputusan pembelian konsumen terhadap produk yang bersangkutan.

Hasil penelitian ini sesuai dengan hasil penelitian sebelumnya yang telah dilakukan oleh Molinari et al. (2008), serta penelitian yang dilakukan oleh Nugraha et al. (2015) menunjukkan hasil yang positif dan signifikan antara pengaruh word of mouth terhadap keputusan pembelian konsumen.

Pengujian hipotesis pada peran word of mouth memediasi pengaruh kualitas produk terhadap keputusan pembelian konsumen dengan menggunakan Uji Sobel menunjukkan peran word of mouth secara signifikan mampu memediasi pengaruh kualitas produk terhadap keputusan pembelian konsumen dengan hasil $\mathrm{Z}$ sebesar $3,4454>1,96$ dengan tingkat nilai Sig $0,000<0,05$, dengan demikian hipotesis keempat dalam hal ini diterima. Hasil penelitian sejalan dengan penelitian sebelumnya yang dilakukan oleh Nugraha et al. (2015) serta penelitian yang dilakukan oleh Anwar (2015) menunjukkan hasil bahwa word of mouth berperan dalam memediasi pengaruh kualitas produk terhadap keputusan pembelian konsumen.

Melalui adanya word of mouth yang tinggi dari konsumen terhadap produk online shop pakaian wanita Georgioswomen mengimplikasikan bahwa kualitas produk yang dimiliki Georgioswomen baik dan hal tersebut menyebabkan adanya word of mouth yang bersifat positif yang kemudian berhasil membuat konsumen tertarik dan memutuskan untuk melakukan suatu keputusan pembelian terhadap produk yang bersangkutan.

Implikasi hasil penelitian ini menekankan pada manfaat nyata dari hasil penelitian untuk mendorong online shop yang telah memiliki penilaian yang positif dimata konsumen agar mampu memiliki daya saing yang lebih kuat di pasarnya dan tetap mampu memuaskan konsumen terhadap produknya yaitu salah satunya dengan cara memasarkan produk dengan kualitas yang baik. Memasarkan suatu produk dengan kualitas yang baik akan dapat menciptakan nilai persepsi yang positif dimata konsumen dan menumbuhkan kepercayaan terhadap produk yang bersangkutan. Sehingga memunculkan niat konsumen untuk melakukan keputusan pembelian dan kemudian menggunakan produk tersebut. Beberapa implikasi strategis dari hasil penelitian:

Kualitas produk telah terbukti secara positif dan signifikan mempengaruhi word of mouth dan keputusan pembelian, oleh karena itu pemasar harus selalu menjaga kualitas dari setiap produk yang diciptakan guna meningkatkan keputusan pembelian konsumen terhadap produk tersebut dan memperkuat kepercayaan konsumen akan suatu produk. Hal ini harus menjadi perhatian bagi Georgioswomen, agar konsumen mempunyai pandangan yang positif terhadap 
produk Georgioswomen. Hal ini tentu akan menguntungkan pihak pemasar karena selain produknya mempunyai nilai kualitas yang positif dimata konsumen, produk tersebut juga memiliki peluang lebih besar untuk dibeli oleh konsumen.

Word of mouth telah terbukti secara positif dan signifikan mampu mempengaruhi munculnya suatu keputusan pembelian dari calon konsumen maupun konsumen terhadap produk online shop pakaian wanita Georgioswomen yang merupakan suatu bentuk cara promosi yang dianggap nyata dan jujur karena konsumen mendengar langsung penilaian terhadap produk melalui word of mouth yang diberikan oleh kerabat ataupun orang lain. Secara keseluruhan, word of mouth yang baik terhadap produk Georgioswomen membuat produknya laku di pasaran dan mampu menarik konsumen baru.

Keterkaitan antara kualitas produk, word of mouth, dan keputusan pembelian bisa dijadikan tolak ukur bagi pihak Georgioswomen dalam hal melihat peluang pasar dengan menjual pakaian wanita dengan mempertahankan kualitas bahan dan kualitas produk yang baik. Adanya bantuan word of mouth kepada orang lain mengenai produk pakaian Georgioswomen juga akan sangat membantu mempengaruhi calon konsumen untuk melakukan keputusan pembelian terhadap produk yang bersangkutan.

Keterbatasan penelitian yang dapat ditarik dari penelitian ini adalah responden dari penelitian ini seluruhnya berjenis kelamin perempuan, sehingga untuk mengumpulkan hasil dari kuisioner penelitian terbilang memakan waktu yang lebih lama daripada menggunakan responden penelitian yang berjenis kelamin laki-laki dan perempuan.

\section{SIMPULAN DAN SARAN}

Berdasarkan hasil pembahasan penelitian yang telah dilakukan, maka dapat disimpulkan bahwa kualitas produk berpengaruh positif dan signifikan terhadap word of mouth. Hasil ini berarti bahwa semakin baik nilai persepsi suatu kualitas produk di mata konsumen, maka akan semakin baik word of mouth yang terjadi terhadap online shop produk pakaian wanita Georgioswomen.

Kualitas produk berpengaruh positif dan signifikan terhadap keputusan pembelian. Hasil ini berarti bahwa semakin baik nilai persepsi suatu kualitas produk di mata konsumen, maka semakin meningkat keputusan pembelian terhadap online shop produk pakaian wanita Georgioswomen.

Word of mouth berpengaruh positif dan signifikan terhadap keputusan pembelian. Hasil ini berarti bahwa semakin baik dan positif word of mouth yang terjadi, hal tersebut menyebabkan adanya peningkatan didalam keputusan pembelian dari konsumen terhadap online shop produk pakaian wanita Georgioswomen.

Word of mouth secara signifikan berperan dalam mempengaruhi hubungan antara kualitas produk terhadap keputusan pembelian produk online shop Georgioswomen. Hal ini berarti bahwa word of mouth konsumen yang baik tentang kualitas produk menyebabkan adanya keputusan pembelian dari konsumen terhadap produk dari online shop Georgioswomen.

Berdasarkan hasil analisis dan simpulan, maka saran yang dapat diberikan kepada pihak - pihak yang memerlukan yaitu kualitas produk dalam penelitian ini 
diukur dengan menggunakan lima indikator, dan dari ke lima indikator tersebut produk dari Georgioswomen terasa nyaman dipakai mendapatkan nilai rata-rata terendah. Oleh karena itu, pihak Georgioswomen diharapkan dapat meningkatkan kualitas produk dengan cara memilih bahan pakaian yang terasa lebih nyaman ketika digunakan, misalnya dengan menggunakan kain yang tidak panas ketika dipakai sehingga konsumen merasa nyaman ketika menggunakan produk tersebut.

Word of mouth dalam penelitian ini diukur dengan menggunakan empat indikator, dimana dari ke empat indikator konsumen mengetahui produk Georgioswomen dari orang lain mendapatkan nilai rata-rata terendah. Berkaitan dengan hal ini, Georgioswomen diharapkan mampu memberikan word of mouth yang lebih kepada para konsumennya, misalnya dengan memanfaatkan konsumennya dengan cara mengajak teman dan kerabat untuk berbelanja di Georgioswomen serta memanfaatkan kekuatan media sosial sehingga informasi tentang produk lebih cepat tersampaikan kepada konsumen, misalnya ketika mengadakan sale.

Keputusan pembelian dalam penelitian ini diukur dengan menggunakan empat indikator, dimana dari ke empat indikator konsumen menyeleksi berbagai alternatif untuk melakukan pembelian terhadap produk Georgioswomen mendapat nilai terendah, oleh karena itu Georgioswomen perlu memikirkan beberapa alternatif yang dapat diberikan kepada konsumen agar konsumen merasa nyaman didalam melakukan suatu keputusan pembelian. Misalnya, ketika konsumen tidak bisa pergi atau berbelanja ke toko, Georgioswomen menyediakan alternatif lain dengan cara memanfaatkan adanya kurir didalam penyampaian barang dari Georgioswomen kepada konsumen. Bagi pelaku usaha sejenis, dapat mengadopsi apa yang telah dilakukan oleh Georgioswomen di dalam menjalankan bisnisnya, sehingga mampu bertahan di tengah persaingan pasar yang ada.

Bagi peneliti selanjutnya diharapkan dapat memperluas cakupan wilayah penelitian misalnya dengan mengambil responden tidak hanya di wilayah Denpasar, melainkan bisa di wilayah lain seperti Badung, Tabanan, atau Gianyar dan sebagainya, mengingat Georgioswomen merupakan online shop jadi sudah pasti memiliki cakupan pasar tidak hanya di wilayah Denpasar.

\section{REFERENSI}

Abdullah, T., \& Tantri, F. (2012). Manajemen Pemasaran. Jakarta: Rajagrafindo Persada.

Alves, S., Abrantes, J. L., Antunes, M. J., Seabra, C., \& Herstein, R. (2016). WOM antecedents in backpacker travelers. Journal of Business Research, 69(5), 1851-1856.

Anis, L. M., Suharyono, \& Sunarti. (2015). Pengaruh Kualitas Produk terhadap Internasional Brand Image Serta Dampaknya terhadap Keputusan Pembelian (Studi pada Mahasiswa pembeli dan pengguna Laptop Lenovo di Fakultas Ilmu Administrasi Universitas Brawijaya). Jurnal Administrasi Bisnis (JAB, 
$28(2), 1-6$.

Anwar, I. (2015). Pengaruh harga dan kualitas produk terhadap keputusan pembelian "Bunchbead Kota Malang." Jurnal Ilmu Dan Riset Manajemen, $4(12)$.

Audrain-Pontevia, A.-F., N'Goala, G., \& Poncin, I. (2013). A good deal online: The Impacts of acquisition and transaction value on E-satisfaction and Eloyalty. Journal of Retailing and Consumer Services, 20, 445-452.

Casaló, L. V., Flavián, C., \& Guinalíu, M. (2008). The role of satisfaction and website usability in developing customer loyalty and positive word-of-mouth in the e-banking services. International Journal of Bank Marketing, 26(6), 399-417. https://doi.org/10.1108/02652320810902433

Dzian, M., Triznova, M., Kaputa, V., \& Supin, M. (2016). The Analysis of WOM in Slovak Republic and Impact of WOM on Consumers' The analysis of WOM in Slovak Republic and impact of WOM on consumers 'purchasing decision. Procedia Economics and Finance, 26(January), 975-981. https://doi.org/10.1016/S2212-5671(15)00919-3

Irwanto, A., Rohman, F., \& Noermijati. (2013). Analisis Pengaruh Kualitas Produk dan Strategi Harga terhadap Kepuasan Pelanggan, dan Pengaruhnya pada Terbentuknya Word-of-mouth di Perumahan Madani Group Jabodetabek. Jurnal Aplikasi Manajemen, 11(1), 85-94.

Ismail, A. R., \& Spinelli, G. (2012). Effects of brand love, personality and image on word of mouth: The case of fashion brands among young consumers Journal of Fashion Marketing and Management mouth: The case of fashion brands among young consumers. Journal of Fashion Marketing and Management, 16(4), 386-398. https://doi.org/10.1108/13612021211265791

Iswayanti, I. P. (2010). Analisis Pengaruh Kualitas Produk, Kualitas Layanan, Harga dan Tempat Terhadap Keputusan Pembelian. Universitas Diponegoro.

Kotler, P., \& Keller, K. L. (2012). Manajemen Pemasaran (Keduabelas). Jakarta: Erlangga.

Kotler, P. T., \& Armstrong, G. (2013). Principles of Marketing (Seventeen). New York: Pearson.

Lerrthaitrakul, W., \& Panjakajornsak, V. (2014). The Impact of Electronic Wordof-Mouth Factors on Consumers' Buying Decision-Making Processes in the Low Cost Carriers: A Conceptual Framework. International Journal of Trade, Economics and Finance, 5(2), 142-146. https://doi.org/10.7763/IJTEF.2014.V5.357 
Luthfia, W. E. (2012). Analisis Pengaruh Kualitas Produk, Kualitas Layanan, dan Harga Terhadap Keputusan Pembelian Pada Coffee Shop Kofisyop Tembalang. Universitas Diponegoro.

Maria, K. D., Kindangen, P., \& Rumokoy, F. S. (2016). The Effect of Electronic Word of Mouth on Consumer Buying Decision in Lazada. Jurnal EMBA, 4(1), 1086-1095.

Martín, S. san, Prodanova, J., \& Torres, N. J. (2015). The impact of age in the generation of satisfaction and WOM in mobile shopping. Journal of Retailing and Consumer Services, 23, 1-8. https://doi.org/10.1016/j.jretconser.2014.11.001

Molinari, L. K., Abratt, R., \& Dion, P. (2008). Satisfaction, quality and value and effects on repurchase and positive word $\square$ of $\square$ mouth behavioral intentions in a B2B services context. Journal of Services Marketing, 22(5), 363-373. https://doi.org/10.1108/08876040810889139

Nugraha, F. A. A., Suharyono, \& Kusumawat, A. (2015). Pengaruh word of mouth terhadap Keputusan Pembelian dan Kepuasan Konsumen (Studi pada konsumen kober mie setan jalan simpang Soekarno-Hatta nomor 1-2 Malang). Jurnal Administrasi Bisnis (JAB), 22(1), 1-7.

Oladepo, O. I., \& Odunlami, S. A. (2015). The Influence of Brand Image and Promotional Mix on Consumer Buying Decision- A Study of Beverage Consumers in Lagos State, Nigeria. British Journal of Marketing Studies, 3(4), 97-109.

Olson, J. C., \& Paul, P. J. (2014). Perilaku Konsumen dan Strategi Pemasaran (Sembilan). Jakarta: Salemba Empat.

Ong, I. A., \& Sugiharto, S. (2013). Analisa pengaruh strategi diferensiasi, citra merek, kualitas produk dan harga terhadap keputusan pembelian pelanggan di cincau station Surabaya. Jurnal Manajemen Pemasaran, 1(2), 1-11.

Puspasari, A. (2014). Pengaruh Kualitas Produk terhadap Word of Mouth melalui Kepuasan Pelanggan. Jurnal Ilmu Manajemen, 2(4), 1737-1748.

Ratanavilaikul, B. (2018). Customer Perceived Value, Satisfaction, and Behavioral Intentions in the Logistic Industry. AU J. Management, 10(2), 63-71.

Ries, A., \& Trout, J. (2002). Positioning: The Battle For Your Mind. Jakarta: PT. Salemba Emban Patria.

Rijswijk, W. van, \& Frewer, L. J. (2008). Consumer Perceptions of Food Quality and Safety and Their Relation to Traceability. British Food Journa, 110(10), 1034-1046. https://doi.org/10.1108/00070700810906642 
Rukhiana, L. N. (2017). Pengaruh Produk dan Harga terhadap Word of Mouth melalui Kepuasan Konsumen. Jurnal Ilmu Dan Riset Manajemen, 6(7).

Rusadi, Y. A., \& Sujito. (2012). Analisis Pengaruh Kualitas Produk, Kualitas Pelayanan terhadap WOM Positif dengan Kepuasan Sebagai Variabel Intervening. Jurnal Ilmiah USM, 2(6), 33-48.

Sääksjärvi, M., \& Samiee, S. (2011). Relationships among Brand Identity, Brand Image and Brand Preference: Differences between Cyber and Extension Retail Brands over Time. Journal of Interactive Marketing, 25(3), 169-177. Retrieved from 10.1016/j.intmar.2011.04.002

Sugiyono. (2017). Metode Penelitian Kuantitatif, Kualitatif, dan R\&D. Bandung: Alfabeta.

Sumarwan, U. (2015). Perilaku Konsumen: Teori dan Penerapannya dalam Pemasaran (Kedua). Bogor: Penerbit Ghalia Indonesia.

Supranto, \& Limakrisna, N. (2011). Perilaku Konsumen dan Strategi Pemasaran (Kedua). Jakarta: Mitra Wacana Media.

Tangkuman, R. S., \& Saerang, D. P. E. (2016). The Effect of Product Placement in Movies and Celebrity Endorsement on Consumer Purchase Intention of Samsung Smartphone in Manado. Jurnal EMBA, 4(4), 1164-1172.

Tjahjono, A., Semuel, H., \& Brahmana, R. K. M. R. (2013). Analisa Marketing Mix, Lingkungan Sosial, Psikologi Terhadap Keputusan Pembelian Online Pakaian Wanita. Jurnal Manajemen Pemasaran Petra, 1(2), 1-9.

Vibiznews-Sales, \& Marketing. (2007). Buzz Marketing Paling efektif di Indonesia. Journal of Emosional Benefit. Retrieved from http://management.co.id/ journal/index/category/sales_marketing/45/30.htm

Wibowo, S. F., \& Karimah, M. P. (2012). Pengaruh Iklan Televisi dan Harga terhadap Keputusan Pembelian Sabun Lux (Survey pada Pengunjung Mega Bekasi Hypermall). Jurnal Riset Manajemen Sains Indonesia (JRMSI), 3(1), $1-15$.

Widiarsa, I. B. I. S., \& Sulistyawati, E. (2018). Peran Keunggulan Kompetitif Memediasi Pengaruh Green Marketing terhadap Keputusan Pembelian (Studi Pada Perusahaan Earth Café di Seminyak). E-Jurnal Manajemen Unud, 7(7), 3442-3470.

Wijaya, T. (2011). Manajemen Kualitas Jasa. Jakarta: PT. Indeks. 